\title{
THERMOTHERAPY AS A MICROBIAL CONTAMINANT-REDUCING AGENT IN MICROPROPAGATION OF BAMBOO ${ }^{1}$
}

\author{
GUSTAVO RUBENS DE CASTRO TORRES ${ }^{2 *}$, FLAVIA PAIVA COUTINHO², BIANCA GALÚCIO PEREIRA \\ ARAÚJO ${ }^{2}$, GIOVANNA PEREIRA DE ABREU², RUI SALES JÚNIOR ${ }^{3}$
}

\begin{abstract}
The aim of the research was to evaluate the effectiveness of thermotherapy by humid heat of nodal segments to reduce the incidence of microbial contaminants in the introduction phase of the in vitro propagation of Bambusa vulgaris. Two independent experiments were carried out in a completely randomized design using a $4 \times 2$ factorial arrangement, four levels of temperature $\left(25,30,40\right.$ and $\left.50{ }^{\circ} \mathrm{C}\right)$ versus two treatment time intervals (5 or $10 \mathrm{~min}$ ). Each treatment was composed of nine replications, corresponding to one single-nodal segment obtained from primary or secondary branches, in sucrose-free Murashige and Skoog medium with half the concentration of salts, supplemented with $6.5 \mathrm{~g} \mathrm{~L}^{-1}$ agar, $50 \mathrm{mg} \mathrm{L}^{-1}$ citric acid, $50 \mathrm{mg} \mathrm{L}^{-1}$ ascorbic acid, $200 \mathrm{mg} \mathrm{L}^{-1}$ chloramphenicol and $2 \mathrm{mg} \mathrm{L}^{-1} \mathrm{~N}^{6}$-benzylaminopurine. Isolation of prevalent mold fungi per repetition was conducted, and identification at genus level obtained from microcultures. The treatments corresponding to $50{ }^{\circ} \mathrm{C}$ for 5 or 10 min reduced significantly the fungal contamination that occurred at $11 \%$ and $0 \%$, respectively, in nodal segments from primary branches, and $0 \%$ and $11 \%$, respectively, in those from secondary ones. Fungi of genera Alternaria, Bipolaris and Curvularia were isolated from both types of segment, and Cladosporium from secondary branches only. The lowest percentages of mycelial growth detected in nodal segments submitted to both binomials demonstrated the effectiveness of the technique to reduce fungal contamination despite negative interference on sprouting.
\end{abstract}

Keywords: Thermal treatment. Microorganisms. Bambusa vulgaris.

\section{TERMOTERAPIA COMO AGENTE REDUTOR DE CONTAMINANTES MICROBIANOS NA MICROPROPAGAÇÃO DO BAMBU}

\begin{abstract}
RESUMO - O objetivo da pesquisa foi avaliar a eficácia da termoterapia por calor úmido em segmentos nodais para reduzir a incidência de contaminantes microbianos na fase de introdução da propagação in vitro de Bambusa vulgaris. Dois experimentos independentes foram conduzidos em delineamento inteiramente casualizado, em arranjo fatorial $4 \times 2$, quatro níveis de temperatura $\left(25,30,40\right.$ e $\left.50{ }^{\circ} \mathrm{C}\right) \times$ dois intervalos de tempo de exposição ao tratamento (5 ou 10 minutos). Cada tratamento foi composto por nove repetições correspondentes a um segmento nodal de uma gema obtido de ramo primário ou secundário, em meio de Murashige e Skoog sem sacarose, com metade da concentração de sais, suplementado com $6,5 \mathrm{mg} \mathrm{L}^{-1}$ de ágar, $50 \mathrm{mg} \mathrm{L}^{-1}$ de ácido cítrico, $50 \mathrm{mg} \mathrm{L}^{-1}$ de ácido ascórbico, $200 \mathrm{mg} \mathrm{L}^{-1}$ de cloranfenicol e $2 \mathrm{mg} \mathrm{L}^{-1} \mathrm{de} \mathrm{N}^{6}$ benzilaminopurina. Isolamento de fungos filamentosos prevalentes nas repetições foi realizado, e, a partir de microcultivos, identificados ao nível de gênero. Os tratamentos correspondentes a $50{ }^{\circ} \mathrm{C}$ por 5 min e por 10 min reduziram significativamente a contaminação fúngica que ocorreu em $11 \%$ e $0 \%$, respectivamente, nos segmentos nodais de ramos primários e em $0 \%$ e $11 \%$, respectivamente, nos secundários. Fungos dos gêneros Alternaria, Bipolaris e Curvularia foram isolados de segmentos nodais dos dois tipos de ramos e Cladosporium apenas de ramos secundários. Os baixos percentuais de crescimento micelial em segmentos nodais submetidos a ambos binômios demonstraram a eficácia da técnica em reduzir a contaminação fúngica apesar da interferência negativa sobre a brotação.
\end{abstract}

Palavras-chave: Tratamento térmico. Microrganismos. Bambusa vulgaris.

\footnotetext{
${ }^{*}$ Corresponding author

${ }^{1}$ Received for publication in 08/03/2018; accepted in 05/06/2019.

${ }^{2}$ Centro de Tecnologias Estratégicas do Nordeste, Recife, PE, Brazil; gustavorubenstorres01@gmail.com - ORCID: 0000-0002-9040-0184, flaviapaco@hotmail.com - ORCID: 0000-0002-2233-199X, bianca.araujo@cente.gov.br - ORCID: 0000-0002-4163-0274, ginna.abreu@outlook.com - ORCID: 0000-0002-7339-7390.

${ }^{3}$ Center for Agrarian Sciences, Universidade Federal Rural do Semi-Árido, Mossoró, RN, Brazil; jrrui@hotmail.com - ORCID: 0000-00019097-0649.
} 


\section{INTRODUCTION}

Bamboo (Bambusa vulgaris Schrad., ex J.C. Wendl.), a plant of the family Poaceae, presents as its center of origin Asia, where the greatest diversity of species is found. Studies show the presence of 258 native bamboo species, distributed in two tribes, Olyreae and Bambuseae, and 35 genera in Brazil (FILGUEIRAS et al., 2015). The country stands out for its potential for exploration of the grass not only because it is the one of the New World countries with the greatest diversity of species but mainly for encouraging the development of its culture through Law 12.484 of 2011 which instituted the National Policy for Incentives for the Sustainable Management and Cultivation of Bamboo - PNMCB (TORRES; HOULLOU; SOUZA, 2016).

Among the various uses of bamboo are the production of long-fiber cellulose and use in reforestation programs, as well as its high economic and environmental value (LIN; HUANG; FANG, 2012). The largest commercial planting area in the world exceeds $108 \mathrm{~km}^{2}$ and is distributed among the Brazilian states of Maranhão, Paraíba and Pernambuco (GENEROSO, 2014).

The traditional methods of propagating bamboo (division of clumps, rhizomes and stems) limit the establishment of commercial plantations, since they are laborious, expensive and of low yield, micropropagation being an alternative for the production of seedlings (GENEROSO, 2014). However, one of the most common problems in micropropagation is microbial contamination, which is a limiting factor since the culture media are excellent sources of nutrients for the growth of microorganisms (MSOGOYA et al., 2012).

A reduction of microbial contamination is described in published protocols on micropropagation of bamboo species as being obtained by immersing the explants in ethanol, sodium hypochlorite and mercuric chloride solutions in isolation or combination (ANAND; BRAR; SOOD, 2013; SHARMA; SARMA, 2013). Also mentioned is the reduction of losses from contamination by using those solutions associated with the pre-treatment of explants with fungicides and antibiotics such as Bavistin ${ }^{\circledR}$, streptocyclin and rifampicin (ALI et al., 2009), Bavistin ${ }^{\circledR}$ and streptomycin (ARYA; ARYA, 2009) and Mancozeb $^{\circledR}$ and gentamicin (MUDOI; SAIKIA; BORTHAKHUR, 2014).

The contamination in micropropagation comes from epiphytic and endophytic microorganisms, the reason why antimicrobial products with superficial action do not guarantee asepsis of the material (TORRES; HOULLOU; SOUZA, 2016). Add to this the fact of working with products that pose risks to health and the environment, and the possibility of microorganisms becoming resistant. Thus, it is necessary to test alternative control techniques with action on a broad spectrum of microorganisms, without the use of chemical products. In this sense, dry or wet heat thermotherapy is a viable option in phytosanitary procedures for the control and/or eradication of fungi transmitted by seeds (MANCINI; ROMANAZZI, 2014).

In view of this scenario, the objective of this research was to test the efficacy of humid heat thermotherapy on nodal segments of primary and secondary branches of $B$. vulgaris to reduce contamination during the introduction phase of the micropropagation of the species, as well as to identify at the genus level the fungi which were expressed as contaminants.

\section{MATERIAL AND METHODS}

The research was conducted in April 2016, and it was based on the independent conduct of two experiments in a completely randomized design in a $4 \times 2$ factorial arrangement corresponding to the combination of four temperature levels $(25,30,40$ and $50{ }^{\circ} \mathrm{C}$ ) and two exposure times to each temperature level separately (5 and $10 \mathrm{~min}$ ). Each treatment was composed of nine replicates, each corresponding to a nodal segment with a swollen and non-sprouted bud, presenting $2 \mathrm{~cm}$ of internode above the bud and $2 \mathrm{~cm}$ of internode below the leaf scar, according to Torres et al. (2016). The nodal segments were deposited in test tubes containing $20 \mathrm{~mL}$ of MS semi-solid culture medium, as described by Murashige and Skoog (1962), with half of the salt concentration, supplemented with $6.5 \mathrm{mg} \mathrm{L}^{-1}$ of Aldrich ${ }^{\circledR}$ agar, $50 \mathrm{mg} \mathrm{L}^{-1}$ of citric acid, $50 \mathrm{mg} \mathrm{L}^{-1}$ of ascorbic acid, $200 \mathrm{mg} \mathrm{L}^{-1}$ of chloramphenicol, $2 \mathrm{mg} \mathrm{L}^{-1}$ of Sigma ${ }^{\circledR} \mathrm{N}^{6}$ benzylaminopurine (BAP) and, according to Torres, Houllou and Souza (2016), without sucrose.

Experiments I and II were installed with a 20-day interval between them using as the source of explants nodal segments obtained from primary and secondary branches, respectively. The branches were collected in the central third of 2-year-old stems with their identified according to Nath, Das and Das (2008) issued from mother clumps over 40 years old, located in the neighborhood of Dois Irmãos $\left(8^{\circ} 44^{\prime} 31.2^{\prime \prime} \mathrm{S}\right.$ and $\left.34^{\circ} 56^{\prime} 34.02^{\prime \prime} \mathrm{W}\right)$ in the city of Recife, Pernambuco State, Brazil.

The collected branches were taken to the laboratory and washed in tap water for the subsequent selection of the segment that would be the donor of nodal segments, being defined as the one containing the most central buds, counting as the first one of the branch the most apical one from which the covering leaf was eliminated manually without resistance. In the case of the primary branches, with an average number of 12 buds, the segments were selected with buds from the fourth to 
the eighth position, and in the secondary ones, with an average number of five buds, they were selected with buds from the third to the fourth position.

The diameter of 20 nodal segments of each origin was measured separately with a pachymeter at $1 \mathrm{~cm}$ below the leaf scar. Data were submitted to analysis of variance and the means were compared by the $t$-test at a $5 \%$ level of error probability.

The nodal segments obtained from primary and secondary branches were separately immersed in $4 \mathrm{~mL} \mathrm{~L}^{-1}$ Derosal $500 \mathrm{SC}^{\circledR}$ (Carbendazim concentrate $500 \mathrm{~g} \mathrm{~L}^{-1}$, Bayer S/A) and $200 \mathrm{mg} \mathrm{L}^{-1}$ of chloramphenicol solution for $2 \mathrm{~h}$ under stirring and rinsed in sterile distilled water. Subsequently, sets composed of nine nodal segments of each type of branch were deposited in eight flasks with $200 \mathrm{~mL}$ capacity containing sterile distilled water and treated to the temperature levels $25,30,40$ and $50{ }^{\circ} \mathrm{C}$ for 5 and $10 \mathrm{~min}$ in a water bath, separately. The treatments, in both experiments, corresponding to nodal segments treated with $25^{\circ} \mathrm{C}$ at 5 and $10 \mathrm{~min}$ were considered as controls. This temperature was registered in the laboratory, and these treatments were not submitted to thermotherapy.

The water contained in the flasks was removed after the heat treatment, leaving the nodal segments, now explants, at room temperature $\left(25^{\circ} \mathrm{C}\right)$ for $10 \mathrm{~min}$. The explants were manipulated in a laminar flow chamber for chemical disinfestation, according to Torres, Houllou and Souza (2016), including immersion in $70 \%$ ethanol solution (water: alcohol, v:v) for $3 \mathrm{~min}$, immersion in $1 \%(\mathrm{v}: \mathrm{v})$ sodium hypochlorite solution for $10 \mathrm{~min}$, rinsing in sterile distilled water once for $1 \mathrm{~min}$ and immersion in $1 \%$ sodium hypochlorite solution (v:v) for 10 min, followed by three consecutive rinses with sterile distilled water of $1 \mathrm{~min}$ each.

After disinfestation, $1 \mathrm{~mm}$ from the lower and upper parts of each explant was cut off and they were individually deposited vertically in test tubes containing $20 \mathrm{~mL}$ of the MS semi-solid culture medium described above, so that the leaf scar region entered in contact with the medium. The test tubes were kept in a growth room at $24 \pm 2{ }^{\circ} \mathrm{C}$, with a $16 \mathrm{~h}$ photoperiod under $40 \mu \mathrm{mol} \mathrm{m} \mathrm{m}^{-2} \mathrm{~s}^{-1}$ luminosity.

An evaluation was performed 21 days after the release of the experiments to analyze the average number of explants with: necrosis in the bud, fungal contamination, bacterial contamination and sprouted buds. Data were submitted to analysis of variance and the means were compared by the Tukey test at a $5 \%$ level of error probability.

The fungal colonies with the highest frequency of growth on explants per repetition were selected based on macroscopic characteristics (appearance and color) 21 days after establishment of the experiments. Isolations were performed by fragmentation of mycelium, transferring them to Petri dishes containing potato dextrose agar (PDA) culture medium, and they were kept at room temperature for 14 days, during which the fungi that grew were purified as well by fragmentation of mycelium and cultivation in PDA.

The isolates which remained active were identified at the generic level, using a classical taxonomy (MANAMGODA et al., 2014; WOUDENBERG et al., 2015), based on the macroscopic characteristics of the colonies and microscopic characteristics from the establishment of microcultures of specimens.

\section{RESULTS AND DISCUSSION}

According to analysis of the data, no significant interaction was identified between the factors time and temperature in any of the variables evaluated in both experiments. The treatments corresponding to $50{ }^{\circ} \mathrm{C}$ for 5 or $10 \mathrm{~min}$ presented a significantly higher average number of explants with necrosis in the bud in relation to the others that did not differ between them in the two experiments. The result indicated that the temperature of $50{ }^{\circ} \mathrm{C}$ was high enough to cause damage to the buds, even if exposed for $5 \mathrm{~min}$. The percentage of explants with necrosis in the bud in the treatments at $50{ }^{\circ} \mathrm{C}$ for 5 or $10 \mathrm{~min}$ was higher, in absolute value, in explants from the primary branches $(88 \%)$ than in those from secondary ones, $56 \%$ and $44 \%$, for 5 and $10 \mathrm{~min}$, respectively (Table 1), indicating that there is a greater susceptibility to necrosis due to the age of the organ in view of the changes in tissue constitution throughout development. According to Liese (1985), bamboo stem tissues ripen in a year, with changes occurring in the proportion of lignin and carbohydrates in this period, and the same can happen with branches.

Comparison between the data of the experiments, conducted independently, showed that in the first, eight treatments showed explants with necrosis in the bud, and four in the second one (Table 1), which evidences the possibility of greater susceptibility of the tissues of primary branches to necrosis as a function of age. Ramanayake and Yakandawala (1997) found, in the phenology of Dendrocalamus giganteus Wall. ex Munro, that for 6 months the sprouting of primary branches from stem buds increases significantly each month, until stabilization, and thereafter initiates the sprouting of secondary branches from the buds of primary ones. Therefore, any primary branch sprouted when the secondary ones are formed will be younger than these. In the present research, if this same phenomenon happens in $B$. vulgaris, the primary branches would be younger than the secondary ones collected in the same month in which the experiments were installed. This fact explains the age difference between secondary and primary branches and the greater susceptibility of buds in these ones to necrosis. 
Table 1. Average number and percentage of explants from primary and secondary branches of Bambusa vulgaris: with necrosis in the bud, fungal contamination, bacterial contamination and sprouted bud at 21 days after exposure to thermotherapy.

\begin{tabular}{|c|c|c|c|c|c|c|c|c|c|}
\hline \multirow{3}{*}{$\begin{array}{l}\text { Temp. } \\
\left({ }^{\circ} \mathrm{C}\right) / \text { time } \\
(\mathrm{min})\end{array}$} & \multirow{3}{*}{ Total } & \multicolumn{4}{|c|}{$\begin{array}{l}\text { Experiment I } \\
\text { Explants from primary branches }\end{array}$} & \multicolumn{4}{|c|}{$\begin{array}{c}\text { Experiment II } \\
\text { Explants from secundary branches }\end{array}$} \\
\hline & & \multirow{2}{*}{${ }^{\mathrm{a}} \mathrm{Nec}$} & \multicolumn{2}{|c|}{ Contamination } & \multirow{2}{*}{ disprout } & \multirow{2}{*}{${ }^{\mathrm{a}} \mathrm{Nec}$} & \multicolumn{2}{|c|}{ Contamination } & \multirow{2}{*}{${ }^{\mathrm{d}}$ Sprout } \\
\hline & & & ${ }^{\mathrm{b}_{\mathrm{F}}}$ & ${ }^{\mathrm{c}} \mathrm{B}$ & & & ${ }^{\mathrm{b}} \mathrm{F}$ & ${ }^{\mathrm{c}} \mathrm{B}$ & \\
\hline \multirow{2}{*}{ I- $25 / 5$} & \multirow{2}{*}{$\begin{array}{c}\text { Mean } \\
\%\end{array}$} & $* 2.0 \mathrm{~b}$ & $6.0 \mathrm{ab}$ & $0.0 \mathrm{~b}$ & $1.0 \mathrm{a}$ & $0.0 \mathrm{~b}$ & $9.0 \mathrm{a}$ & $0.0 \mathrm{~b}$ & $0.0 \mathrm{a}$ \\
\hline & & 22 & 67 & 0 & 11 & 0 & 100 & 0 & 0 \\
\hline \multirow{2}{*}{ II- 25/10 } & \multirow{2}{*}{$\begin{array}{c}\text { Mean } \\
\%\end{array}$} & $1.0 \mathrm{~b}$ & $7.0 \mathrm{ab}$ & $1.0 \mathrm{~b}$ & $1.0 \mathrm{a}$ & $0.0 \mathrm{~b}$ & $9.0 \mathrm{a}$ & $1.0 \mathrm{ab}$ & $1.0 \mathrm{a}$ \\
\hline & & 11 & 78 & 11 & 11 & 0 & 100 & 11 & 11 \\
\hline \multirow[b]{2}{*}{ III- $30 / 5$} & \multirow{2}{*}{$\begin{array}{c}\text { Mean } \\
\%\end{array}$} & $1.0 \mathrm{~b}$ & $7.0 \mathrm{ab}$ & $1.0 \mathrm{~b}$ & $0.0 \mathrm{a}$ & $0.0 \mathrm{~b}$ & $8.0 \mathrm{a}$ & $0.0 \mathrm{~b}$ & $0.0 \mathrm{a}$ \\
\hline & & 11 & 78 & 11 & 0 & 0 & 89 & 0 & 0 \\
\hline \multirow[b]{2}{*}{ IV- 30/10 } & \multirow{2}{*}{$\begin{array}{c}\text { Mean } \\
\%\end{array}$} & $1.0 \mathrm{~b}$ & $9.0 \mathrm{a}$ & $0.0 \mathrm{~b}$ & $2.0 \mathrm{a}$ & $1.0 \mathrm{~b}$ & $9.0 \mathrm{a}$ & $1.0 \mathrm{ab}$ & $1.0 \mathrm{a}$ \\
\hline & & 11 & 100 & 0 & 22 & 11 & 100 & 11 & 11 \\
\hline \multirow[b]{2}{*}{ V- $40 / 5$} & \multirow{2}{*}{$\begin{array}{c}\text { Mean } \\
\%\end{array}$} & $1.0 \mathrm{~b}$ & $6.0 \mathrm{ab}$ & $1.0 \mathrm{~b}$ & $0.0 \mathrm{a}$ & $0.0 \mathrm{~b}$ & $9.0 \mathrm{a}$ & $0.0 \mathrm{~b}$ & $0.0 \mathrm{a}$ \\
\hline & & 11 & 67 & 11 & 0 & 0 & 100 & 0 & 0 \\
\hline \multirow[b]{2}{*}{ VI- 40/10 } & \multirow{2}{*}{$\begin{array}{c}\text { Mean } \\
\%\end{array}$} & $1.0 \mathrm{~b}$ & $5.0 \mathrm{~b}$ & $0.0 \mathrm{~b}$ & $1.0 \mathrm{a}$ & $1.0 \mathrm{~b}$ & $9.0 \mathrm{a}$ & $0.0 \mathrm{~b}$ & $2.0 \mathrm{a}$ \\
\hline & & 11 & 56 & 0 & 11 & 11 & 100 & 0 & 22 \\
\hline \multirow[b]{2}{*}{ VII- 50/5 } & \multirow{2}{*}{$\begin{array}{c}\text { Mean } \\
\%\end{array}$} & $8.0 \mathrm{a}$ & $1.0 \mathrm{c}$ & $7.0 \mathrm{a}$ & $0.0 \mathrm{a}$ & $5.0 \mathrm{a}$ & $0.0 \mathrm{~b}$ & $0.0 \mathrm{~b}$ & $1.0 \mathrm{a}$ \\
\hline & & 88 & 11 & 78 & 0 & 56 & 0 & 0 & 11 \\
\hline \multirow[b]{2}{*}{ VIII- 50/10 } & \multirow{2}{*}{$\begin{array}{c}\text { Mean } \\
\%\end{array}$} & $8.0 \mathrm{a}$ & $0.0 \mathrm{c}$ & $8.0 \mathrm{a}$ & $1.0 \mathrm{a}$ & $4.0 \mathrm{a}$ & $1.0 \mathrm{~b}$ & $3.0 \mathrm{a}$ & $0.0 \mathrm{a}$ \\
\hline & & 88 & 0 & 88 & 11 & 44 & 11 & 33 & 0 \\
\hline${ }^{\mathrm{e}}$ C.V. (\%) & & 12.9 & 13.5 & 10.7 & 10.4 & 12.3 & 5.4 & 9.9 & 9.3 \\
\hline
\end{tabular}

*Averages transformed by $\sqrt{x+1}$ for analysis and the original values presented followed by the same letter, in the same column, did not differ significantly between them by the Tukey test $(p>0.05)$. ${ }^{\mathrm{a}} \mathrm{Nec}=$ average number of explants with necrosis in the bud; ${ }^{b} \mathrm{~F}=$ average number of explants with fungal contamination; ${ }^{\mathrm{c}} \mathrm{B}=$ average number of explants with bacterial contamination; ${ }^{\mathrm{d}}$ Sprout $=$ average number of explants with sprouted bud and C.V. (\%) - Coefficient of variation.

The occurrence of necrosis due to thermotherapy according to the age of the tissues was confirmed by Urashima and Grachet (2012) who studied the effect of the technique on sprouting of buds in three sugarcane varieties (Saccharum L. hybrids). These authors identified greater susceptibility to thermal injury of apical and central (younger) buds compared to basal (older) ones when submitted to $50{ }^{\circ} \mathrm{C}$ for $2 \mathrm{~h}$. The highest percentage of necrosis in younger buds was recorded by Torres et al. (2016) in B. vulgaris, even in the absence of thermotherapy. Nodal segments from apical buds with the same length, in culture medium with the same composition as in the present study, showed $10 \%$ necrosis, while nodal segments with central and basal ones did not express the symptom at 21 days. In this research, in the treatments corresponding to $25{ }^{\circ} \mathrm{C}$ for $5 \mathrm{~min}$ and for $10 \mathrm{~min}$, with no thermotherapy, necrosis in buds from primary branches occurred in $22 \%$ and $11 \%$ of buds, respectively, whereas necrosis was absent in the same treatments corresponding to buds from secondary ones (Table 1).

The percentages of fungal contamination observed in treatments corresponding to $50{ }^{\circ} \mathrm{C}$ for 5 min and for $10 \mathrm{~min}$ applied to explants from primary $(11 \%$ and $0 \%)$ and secondary $(0 \%$ and $11 \%)$ branches were significantly lower in relation to the others (Table 1) and they were close to those mentioned by Torres, Houllou and Souza (2016) in explants of $B$. vulgaris. They recorded $12 \%$ contamination at 21 days. The results of the present study were lower than those of Pandey and Singh (2012) who detected $43.3 \%$ contamination when disinfested explants of Dendrocalamus strictus (Roxb.) Nees by immersion in $0.2 \%$ mercuric chloride solution for $15 \mathrm{~min}$, and those described by Mudoi, Saikia and Borthakur (2014) who obtained 
$55 \%$ contamination in explants of Bambusa nutans Wall. ex Munro disinfested by immersion in Tween $20 \quad(5 \%)$ solution, Mancozeb ${ }^{\circledR} \quad(0.1 \%)$ and Gentamycin $(0.1 \%)$ with subsequent immersion in $70 \%$ ethanol solution.

The similarity of the percentages of fungal contamination in both experiments, considering the treatments at $50{ }^{\circ} \mathrm{C}$ for 5 and $10 \mathrm{~min}$, disagrees with Copersucar (1984) regarding the existence of sugarcane stalks still infected after thermal therapy to control ratoon stunting disease. According to them it occurs, in part, due to the larger diameter of these stems, because thinner ones receive heat faster in the interior, inactivating the pathogen. In the present research, although the diameter of the explants of primary branches $(5.95 \pm 0.65 \mathrm{~mm})$ was significantly higher than that of secondary branches $(3.65 \pm 0.37$ $\mathrm{mm})$, the difference was not enough to identify lower percentages of contamination in these ones.

The effectiveness of reducing fungal contamination considering these treatments differs from the results of Marchi et al. (2008) using treatments of $27,40,50$ and $60{ }^{\circ} \mathrm{C}$ for 5 and $10 \mathrm{~min}$ in the thermotherapy of Brachiaria brizantha (Hochst.) Stapf seeds for control of Ustilago operta Syd., P. Syd. and E.J. Butler, because they did not find significant differences between treatments, which may be related to the resistance of the fungal structures of the species focused on in these studies in relation to the temperatures and times tested.

The high percentages of fungal contamination in treatments with temperatures lower than $50{ }^{\circ} \mathrm{C}$ in experiments I $(56 \%$ to $100 \%)$ and II $(89 \%$ and $100 \%$ ) reflected the high level of infection of tissues coming from the field. Several authors (RAMANAYAKE; YAKANDAWALA, 1997; ANAND; BRAR; SOOD, 2013; SHARMA; SARMA, 2013) have reported that a season with more rain events and high air humidity interferes in the fungal contamination rate of bamboo tissues, resulting in elevated percentages in vitro. In fact, from March to April 2016, during which the experiments were installed, monthly rainfall rose from 69.3 to $291.6 \mathrm{~mm}$ (APAC, 2017).

The high fungal contamination in these treatments can also be understood as reported by Copersucar (1984) when affirming that in sugarcane thermotherapy to control ratoon stunting disease, the occurrence of small stalks of three to five buds still infected after treatment at $50{ }^{\circ} \mathrm{C}$ for $2 \mathrm{~h}$ or $54{ }^{\circ} \mathrm{C}$ for $8 \mathrm{~h}$ is due to their being poor conductors of heat, a characteristic attributed to the species' epidermis and type of fiber. In this sense, Liese (1985) described in relation to bamboo that the outer part of the culm is formed by two epidermal cell layers, the inner appearing thicker and highly lignified, and the surface of outermost cells being covered by a cutinized layer with a wax coating. Ghavami and
Marinho (2005) described the structure of bamboo as being composed of long and aligned fibers of cellulose immersed in a lignin matrix concentrated closer to the epidermis. In this way, the chemical constitution of the branches can also represent a restriction to the conduction of heat at temperatures below $50{ }^{\circ} \mathrm{C}$, and fungal structures remain viable in places far from the surface.

The high percentages of bacterial contamination, $88 \%$ in experiment I and $33 \%$ in experiment II (Table 1), exceeded the $10 \%$ at 21 days found by Torres et al. (2016) and $16 \%$ at 23 days observed by Torres, Houllou and Souza (2016), testing the fungicides Derosal ${ }^{\circledR}$, Tairel Plus ${ }^{\circledR}$ and Cetoconazol $^{\circledR}$ added to the culture medium in micropropagation of $B$. vulgaris. The authors used culture medium supplemented with $200 \mathrm{mg} \mathrm{L}^{-1}$ of chloramphenicol, and the absence of this in the present research contributed to the high rates of contamination, which demonstrates the need to associate thermotherapy and antibiotic supplementation of the culture medium.

The average number of explants with sprouted buds did not differ significantly between treatments in both experiments, ranging from $0 \%$ to $22 \%$ (Table 1). The low sprouting percentages observed even in the treatments without the use of the thermotherapy prevented detection of the influence of thermal treatment on the mentioned variable; however, they can represent the effect of the season on mother plants. Sharma and Sarma (2011) stated that in micropropagation of Bambusa balcooa Roxb. there is dependence of bud breaking on the season of the year. In fact, Mudoi, Saikia and Borthakhur (2014) reported for micropropagation of $B$. nutans that in certain cases, the season of explant collection is more important than the selection of the right kind of culture medium, and proved the fact when they detected a significantly smaller percentage of sprouted buds in the rainy season (15\%) compared to the others. The data from the present study confirm that what is reported by these authors - fewer sprouted buds of $B$. nutans observed in the rainy season - occurs with $B$. vulgaris; however, the dependence on established mother plants in the field forces researchers to collect explants even at this time in order not to interrupt the continuous process of micropropagation.

The percentages of sprouting in the control treatments were lower than those found at 21 days by Torres et al. (2016), ranging from $80 \%$ to $100 \%$ in explants from primary branches of $B$. vulgaris collected in January 2016, corresponding to rainfall of $119.6 \mathrm{~mm}$, lower than that recorded in April $(291.6 \mathrm{~mm})$ in the same area (APAC, 2017). The authors used culture medium with the same composition, and nodal segments of the same length as in the present study. 
Isolation and Identification of Fungi

From the 23 isolates of fungi in explants from primary branches, 17 isolates remained active, 15 of which were identified at generic level in decreasing order of prevalence: Curvularia Boedijn, Bipolaris
Shoemaker and Alternaria Nees (Table 2). In the case of explants from secondary branches from 18 isolates, 13 isolates remained active and 12 were identified at a generic level in decreasing order of prevalence: Bipolaris, Alternaria, Curvularia and Cladosporium Link (Table 2).

Table 2. Number of fungal isolates and respective percentages identified at the generic level according to the classical taxonomy obtained from nodal segments of primary and secondary branches of $B$. vulgaris submitted to thermotherapy.

\begin{tabular}{ccccc}
\hline \multirow{2}{*}{ Genus } & \multicolumn{5}{c}{ Fungal Isolates } \\
\cline { 2 - 5 } & \multicolumn{2}{c}{ Primary Branches } & \multicolumn{2}{c}{ Secundary Branches } \\
\hline Alternaria Nees & 1 & Percentage (\%) & Number & Percentage (\%) \\
Bipolaris Shoemaker & 6 & 6.0 & 5 & 38.5 \\
Cladosporium Link & - & 35.3 & 4 & 30.8 \\
Curvularia Boedijn & 8 & - & 1 & 7.7 \\
Mycelia sterilia & 2 & 47.0 & 2 & 15.4 \\
Total & 17 & 11.7 & 1 & 7.7 \\
\end{tabular}

Although microculture in PDA enabled the formation of abundant reproductive structures allowing identification, at the genus level for the majority of the isolates, two from the explants of primary branches $(11.7 \%)$ and one from secondary branches $(7.7 \%)$ were considered Mycelia sterilia (Table 2).

Shen et al. (2014) studied the diversity of endophytic fungi in seeds of Phyllostachys edulis (Carr.) Houz., and identified 16 fungal genera, including Alternaria, Cladosporium and Curvularia. However, only Cladosporium (24\%) was among the three prevalent genera which also included Shiraia Henn (18.9\%) and Colletotrichum Corda (15.4\%). Paynor, David and Valentino (2016) also cited isolation of Cladosporium from bamboo, without citing the species.

The results showed similarity between the genera identified as contaminants of explants from primary and secondary branches, although the prevalence was differentiated in absolute percentage values. In experiment I, Bipolaris and Curvularia corresponded to $82.3 \%$ of identified isolates and, in experiment II, Alternaria and Bipolaris corresponded to $69.3 \%$ (Table 2). The genus Cladosporium was detected only in explants from secondary branches at the lowest percentage (7.7\%) (Table 2). This fact does not invalidate the possibility of detection in tissues of primary branches, since the two types of branches were collected at the same time and from the same clump. According to Heidy, Zhou and Dalisay (2002), most of the fungal species associated with bamboo have been reported in stem and leaf tissues that cover the buds and branches, being less frequent in shoots, roots and inflorescences. It is not known whether they are specific to or are recurrent on certain bamboo tissues.

These authors report that there are more than 1,100 species of bambusicolous fungi (fungi growing on any bamboo substrate, which include leaves, culms, branches, rhizomes and roots), and most of them do not cause diseases in bamboo, but this does not prevent them being pathogenic to other crops, even being associated with grass tissues. Thus, the isolation of fungi of the genera Alternaria, Bipolaris, Cladosporium and Curvularia from explants of the two types of branch highlights the importance of deepening research that identifies the diversity of fungal species associated with $B$. vulgaris tissues. Although they may not cause disease to this alternative host, their presence may maintain pathogenic species in crops of economic interest, increasing the potential for inoculum where diseases occur or introducing them into growing areas where they have not yet occurred.

\section{CONCLUSIONS}

In spite of the negative interference in bud sprouting observed in treatments at $50{ }^{\circ} \mathrm{C}$ for 5 and $10 \mathrm{~min}$ used in thermotherapy, the low percentages of nodal segments from primary and secondary branches contaminated by fungi proved the effectiveness of the mentioned binomials in the reduction of fungal contamination during the introduction phase of $B$. vulgaris micropropagation. However, in relation to bacterial contamination, it is necessary to supplement the culture medium with antibiotics, since the highest occurrence of this was detected in these treatments. The genera Alternaria, Bipolaris and Curvularia were prevalent as contaminants in the in vitro propagation of $B$. vulgaris. The low occurrence of sprouted buds, even in the treatments whose explants were not submitted to thermotherapy, indicates the need to conduct experiments in different seasons of the year to know the real influence of the technique on sprouting in the periods when it is high. 


\section{ACKNOWLEDGEMENTS}

The corresponding author thanks the Conselho Nacional de Desenvolvimento Científico e Tecnológico (CNPq) for granting the PCI-DA grant, process number $313323 / 2015$, to the Direction of the Parque Estadual de Dois Irmãos for the assistance and to the Direction of the Centro de Tecnologias Estratégicas do Nordeste - CETENE.

\section{REFERENCES}

AGÊNCIA PERNAMBUCANA DE ÁGUAS E CLIMA - APAC. Meteorologia - Boletins Pluviométricos Anteriores. APAC: Recife, 2017. Disponível em:<www.apac.pe.gov.br/meteorologia/ boletins_pluviometricos_old.php $>$. Acesso em: 17 mar. 2017.

ALI, A. H. et al. In vitro Organogenesis and simultaneous formations of shoots and roots from callus in Dendrocalamus asper. In: VIII WORLD BAMBOO CONGRESS, 2009, Thailand. Proceedings... Massachusetts: World Bamboo Organization, 2009. v. 6, p. 31-40.

ANAND, M.; BRAR, J.; SOOD, A. In Vitro Propagation of Edible Bamboo Bambusa bambos and Assessment of Clonal Fidelity through Molecular Markers. Journal of Medical and Bioengineering, v. 2, n. 4, p. 257-261, 2013.

ARYA, I. D.; ARYA, S. Propagation of bamboos through culture technology and field plantation. In: VIII WORLD BAMBOO CONGRESS, 2009, Thailand. Proceedings... Massachusetts: World Bamboo Organization, 2009. v. 6, p. 131-143.

COPERSUCAR. Formação de viveiros de cana-deaçúcar, a partir do tratamento térmico de gemas isoladas. Santo Antônio: Centro de Tecnologia COPERSUCAR, 1984. 12 p. (Cadernos COPERSUCAR, Série Melhoramento, 9).

FILGUEIRAS, T. S. et al. Poaceae. In: Lista de espécies da flora do Brasil. Jardim Botânico do Rio de Janeiro, 2015. Disponível em: <http:// floradobrasil.jbrj.gov.br/jabot/floradobrasil/FB193>. Acesso em: 08 jun. 2018.

GHAVAMI, K.; MARINHO, A. Propriedades físicas e mecânicas do colmo inteiro do bambu da espécie Guadua angustifolia. Revista Brasileira de Engenharia Agrícola e Ambiental, v. 9, n. 1, p. 107 $-114,2005$

GENEROSO, A. L. Caracterização Morfológica e Cultivo in vitro de Espécies de Bambu. 2014. $57 \mathrm{f}$.
Dissertação (Mestrado em Genética e Melhoramento de Plantas) - Universidade Estadual Norte Fluminense Darcy Ribeiro, Campos dos Goytacazes, 2014.

HEIDY, K. D.; ZHOU, D.; DALISAY, T. Bambusicolous fungi: A review. Fungal Diversity, v. 9, n. 1, p. 1-14, 2002.

LIESE, W. Anatomy and Properties of Bamboo. Proceedings of the International Bamboo Workshop. China, 1985. p. 196-208.

LIN, X.; HUANG, L.; FANG, W. Bamboo regeneration via embryogenesis and organogenesis. In: Embryogenesis. Sato, Ken-Ichi (Eds.). INTECH: Rijeka, 2012. cap. 16. p. 359-372. Disponível em: $<$ http://www.intechopen.com/books/embryogenesis/ bamboo-regeneration-via-embryogenesis-andorganogenesis>. Acesso em: 08 jun. 2018.

MANAMGODA, D. S. The genus Bipolaris. Studies in Mycology, v. 79, n. 1, p. 221-288, 2014.

MANCINI, V.; ROMANAZZI, G. Seed treatments to control seedborne fungal pathogens of vegetable crops. Pest Management Science, v. 70, n. 6, p. 860 $-868,2014$

MARCHI, C. E. et al. Quimio e termoterapia em sementes e aplicação de fungicidas em Brachiaria brizantha como estratégias no manejo do carvão. Summa Phytopathologica, v. 34, n. 4, p. 321-325, 2008

MSOGOYA, T. et al. Identification and management of microbial contaminants of banana in vitro cultures. Journal of Applied Biosciences, v. 55, n. 1, p. 3987-3994. 2012.

MUDOI, K. D.; SAIKIA, S. P.; BORTHAKHUR, M. Effect of nodal positions, seasonal variations, shoot clump and growth regulators on micropropagation of commercially important bamboo, Bambusa nutans Wall. Ex. Munro. African Journal of Biotechnology, v. 19, n. 19, p. 19611972. 2014.

MURASHIGE, T.; SKOOG, F. A revised medium for rapid growth and bioassays with tobacco tissue culture. Physiologia Plantarum, v. 15, n. 1, p. 473 497. 1962.

NATH, A. J.; DAS, G.; DAS, A. K. Vegetative phenology of three bamboo species in subtropical humid climate of Assam. Tropical Ecology, v. 49, n. 1, p. 85-89, 2008.

PANDEY, B. N.; SINGH, N. B. Micropropagation of Dendrocalamus strictus nees from mature nodal 
explants. Journal of Applied and Natural Science, v. 4, n. 1, p. 5-9. 2012

PAYNOR, K. A.; DAVID, E. S.; VALENTINO, M. J. G. Endophytic fungi associated with bamboo as possible sources of single cell protein using corn cob as a substrate. Mycosphere, v. 7, n. 2, p. 139-147, 2016.

RAMANAYAKE, S. M. S. D.; YAKANDAWALA, $\mathrm{K}$. Micropropagation of the giant bamboo (Dendrocalamus giganteus Munro) from nodal explants of field grown culms. Plant Science, v. 129, n. 2, p. 213-223, 1997.

SHARMA, P.; SARMA, K. P. In vitro propagation of Bambusa balcooa for a better environment. In: International Conference on Advances in Biotechnology and Pharmaceutical Sciences, 2011, Bangkok. Proceedings... Bangkok: Planetary Scientific Research Centre, 2011. p. 248-252.

SHARMA, P.; SARMA K. P. In Vitro propagation of Bambusa tulda: an important plant for better environment. Journal of Enviroment Research and Development, v. 7, n. 3, p. 1216-1223, 2013.

SHEN, X. et al. Diversity and antimicrobial activity of culturable endophytic fungi isolated from moso bamboo seeds. PLoS One, v. 9, n. 4, p. 1-7, 2014.

TORRES, G. R. C.; HOULlOU, L. M.; SOUZA, R. A. Control of contaminants during introduction and establishment of Bambusa vulgaris in vitro. Research in Biotechnology, v. 7, n. 1, p. 58-67, 2016.

TORRES, G. R. C. et al. Efeito da posição de segmentos nodais sobre a contaminação e brotação na micropropagação do bambu. Ciência \& Tecnologia: Fatec-JB, v. 8, n. 1, p. 1-15, 2016.

URASHIMA, A. S.; GRACHET, N. G. Métodos de detecção de Leifsonia xyli subsp. xyli e efeito da termoterapia na brotação das gemas de diferentes variedades de cana-de-açúcar. Tropical Plant Pathology, v. 37, n. 1, p. 57-64, 2012.

WOUDENBERG, J. H. C. Alternaria section Alternaria: Species, formae speciales or pathotypes? Studies in Mycology, v. 82, n. 1, p. 1-21, 2015. 